\title{
STATUS EKONOMI DAN TINGKAT PENDIDIKAN DENGAN KEJADIAN KEK IBU HAMIL DI PUSKESMAS
}

\author{
Rini Febrianti ${ }^{1}$,Rosa Riya ${ }^{2}$, Sumiati ${ }^{3}$ \\ STIKes Keluarga Bunda Jambi ${ }^{123}$ \\ rinifebrianti408@gmail.com¹, rosariya22@yahoo.com², sumsumiati879@gmail.com ${ }^{3}$
}

\begin{abstract}
Risk of maternal death due to childbirth in Indonesia is 1 in 65. The purpose of this research is to find out the relationship between Economic Status and Education Level with Chronic Energy Deficiency events (CED in Pregnant Woman at Talang Banjar Health Center, Jambi City. This research is a research by design using a Cross Sectional approach which aims to see the relationship between Economic Status and Education Level with CED. The population in this study is Pregnant Women who visited at Talang Banjar Community Health Center, Jambi City in 2019. The sample in this study is Accidental Sampling, namely by taking the respondent happened to meet the researcher, this study uses Univariate and Bivariate data analysis. The results of this study indicate (48,3\%) have less Economic Status and (51,7\%) have a capable Economic Status while (58,3\%) have a low Level of Education and $(41,7 \%)$ have a high Level of Education. The relationship between Economic Status and the incidence of CED in Pregnant Woman with p-value 0,036 and OR 0,332(0,114-0,965) this shows that there is a relationship Economic Status and the incidence of CED in Pregnant Woman, and the results of intermediate data analysis Level of Education with the incidence of CED in Pregnant Woman with p-value 0,018 and OR 0,266(0,086-0,826) this shows that there is a relationship Level of Education with the incidence of CED in Pregnant Woman. The conclusion of this research is there is relationship between Economic Status and Education Level with CED in Pregnant Woman.
\end{abstract}

Keywords: CED, Economic Status, and Level of Education

\begin{abstract}
ABSTRAK
Resiko kematian ibu karena melahirkan di Indonesia adalah 1 dari 65. Tujuan penelitian ini adalah untuk mengetahui Hubungan Status Ekonomi dan Tingkat Pendidikan dengan Kejadian Kekurangan Energi Kronik(KEK) pada Ibu Hamil di Puskesmas Talang Banjar Kota Jambi. Penelitian ini merupakan penelitian dengan rancangan penelitian Observasional Analitik dengan menggunakan pendekatan Cross Sectionalyang bertujuan untuk melihat Hubungan Status Ekonomi dan Tingkat Pendidikan dengan kejadian KEK. Populasi dalam penelitian ini adalah Ibu Hamil yang berkunjung di Puskesmas Talang Banjar Kota Jambi tahun 2019. Sampel dalam penelitian ini adalah accidental sampling, yaitu dengan mengambil responden kebetulan bertemu peneliti. penelitian ini menggunakan analisis data secara Univariat dan Bivariat.Hasil penelitian ini menunjukkan (48,3\%) mempunyai Status Ekonomi Kurang dan $(51,7 \%)$ mempunyai Status Ekonomi mampu sedangkan $(58,3 \%)$ memiliki Tingkat Pendidikan rendah dan $(41,7 \%)$ memiliki Tingkat pendidikan tinggi. Hubungan antara Status Ekonomi dengan kejadian KEK pada Ibu Hamil dengan p-value 0,036 dan OR 0,332 $(0,114$ - 0,965) hal ini menunjukkan bahwa ada hubungan Status Ekonomi dengan Kejadian KEK pada Ibu Hamil, dan hasil analisis data antara Tingkat Pendidikan dengan kejadian KEK pada Ibu Hamil dengan $p$-value 0,018 dan OR 0,266 (0,086 - 0,826) hal ini menunjukkan bahwa ada hubungan Tingkat Pendidikan dengan Kejadian KEK pada Ibu Hamil. Kesimpulan penelitian ini adalah ada hubungan Status Ekonomi dan Tingkat Pendidikan dengan kejadian KEK pada Ibu Hamil.
\end{abstract}

Kata kunci:KEK, Status Ekonomi, Tingkat Pendidikikan

\section{PENDAHULUAN}

\section{Latar Belakang}

Riskesdas 2018 menunjukkan prevalensi risiko Kekurangan Energi Kronis (KEK) pada ibu hamil (15-49 tahun) sebesar 17,3\%, khususnya prevalensi tertinggi ditemukan pada usia remaja (15-19 tahun) sebesar 33,5\% dibandingkan dengan kelompok lebih tua (20-24 tahun) sebesar 23,3\% . Asupan makanan menjadi faktor utama yang berisiko terjadinya Kekurangan Energi Kronis (KEK) pada ibu hamil ${ }^{1}$. Hasil Pemantauan Konsumsi Gizi (PKG) yang dilakukan bersamaan dengan pengumpulan data Pemantauan Status Gizi (PSG) tahun 2016 
menunjukkan, baru sebanyak 26,3\% ibu hamil yang memenuhi kecukupan energi dan $29,3 \%$ ibu hamil yang memenuhi kecukupan protein dalam konsumsinya sehari-hari ${ }^{1}$.

Kementrian kesehatan membuat progam bagi ibu hamil risiko Kekurangan Energi Kronis (KEK), yaitu memiliki LILA $<23,5 \mathrm{~cm}$, berupa pemberian makanan tambahan. Hasil Pemantauan Status Gizi (PSG) 2016 didapatkan $79,3 \%$ ibu hamil risiko Kekurangan Energi Kronis (KEK) mendapatkan makanan tambahan lebih besar dari target nasional tahun 2016 sebesar $50 \%^{2}$.

Penelitian yang dilakukan oleh RS Renjani, dkk, (2017) menunjukkan bahwa kejadian Kekurangan Energi Kronis (KEK) pada ibu hamil yang berpendidikan rendah lebih banyak terjadi pada kelompok status yaitu $85 \%$, sementara pada kelompok control hanya 30\%. Hasil uji statistic diperoleh nilai $\mathrm{OR}=13,2$ yang berarti bahwa ibu hamil yang berpendidikan rendah mempunyai peluang 13,2 kali lebih besar mengalami Kekurangan Energi Kronis $(\mathrm{KEK})^{3}$.

Status Ekonomi seseorang mempengaruhi pemilihan makanan yang akan dikonsumsi sehariharinya ${ }^{4}$. Ibu hamil dengan taraf ekonomi yang tinggi kemungkinan besar akan tercukupi kebutuhan gizinya ${ }^{4}$.

Menurut penelitian YD Novitasari, dkk (2019) Variabel status Ekonomi keluarga menunjukkan hasil bahwa terdapat hubungan antara status ekonomi dengan kejadian KEK ibu hamil ${ }^{5}$. Penelitian ini juga sejalan dengan penelitian Laila Rahmi (2016) dengan nilai $\mathrm{p}=0,0032(\mathrm{p}<0,05)$ yang menunjukkan bahwa terdapat hubungan yang bermakna antara status ekonomi dengan kejadian $\mathrm{KEK}^{5}$.

\section{Tujuan Penelitian}

\section{Tujuan Umum :}

Mengetahui Hubungan Status Ekonomi dan Tingkat Pendidikan dengan Kejadian KEK pada Ibu Hamil di Puskesmas Talang Banjar Kota Jambi Tahun 2020.

\section{Tujuan Khusus :}

a. Untuk mengetahui Distribusi Frekuensi Status Ekonomi dengan kejadian KEK pada Ibu Hamil

b. Untuk mengetahui distribusi Frekuensi Tingkat Pendidikan dengan Kejadian KEK

c. Diketahui Hubungan Status Ekonomi dengan Kejadian KEK pada Ibu Hamil

d. Diketahui Hubungan Tingkat Pendidikan dengan Kejadian KEK pada Ibu Hamil

e. Diketahui Hubungan Status Ekonomi dan Tingkat Pendidikan Terhadap Kejadian KEK pada Ibu Hamil.

\section{Hipotesis (Opsional)}

Apakah ada Hubungan Status ekonomi dan pendidikan dengan kejadian Kekurangan Energi Kronis pada ibu hamil di Puskesmas Talang Banjar Kota Jambi

\section{METODE}

Penelitian ini menggunakan desain penelitian observasional analitik dengan pendekatan Cross Sectional untuk mempelajari hubungan antara Status Ekonomi dan Tingkat Pendidikan terhadap Kejadian Kekurangan Energi Kronis (KEK) pada ibu hamil ${ }^{7}$. Dalam Penelitian ini peneliti melakukan observasi atau penilaian pada variabel Status Ekonomi dan Pendidikan secara bersamaan dengan dilakukannya observasi atau penilaian pada variabel ibu hamil dengan $\mathrm{KEK}^{7}$. Populasi dari penelitian ini adalah seluruh ibu hamil yang melakukan pemeriksaan ANC DI Puskesmas Talang Banjar Kota Jambi Tahun 2019 yaitu sebanyak 300 orang $^{8}$. Sampel adalah sebagian dari populasi yang dipilih dengan cara tertentu hingga dianggap dapat mewakili populasi nya ${ }^{8}$. Teknik pengambilan sampel di lakukan menggunakan teknik accidental sampling yaitu penelitian dilakukan dengan mengambil responden kebetulan bertemu atau bersedia ditempat penelitian. Jumlah sampel sebanyak 60 Responden sebagai sampel untuk penelitian ini ${ }^{8}$.

Pada penelitian ini menggunakan jenis data khusus yaitu data yang menggambarakan variabel yang akan diteliti antara lain Status Ekonomi dan Tingkat Pendidikan terhadap kejadian KEK pada Ibu Hamil di Puskesmas Talang Banjar Kota Jambi ${ }^{9}$.

Tekhnik Analisis data dengan analisis univariat ini bertujuan untuk mengetahui tentang distribusi frekuensi atau proporsi masing-masing variabel yang diteliti, baik variabel independen maupun dependen ${ }^{10}$. Analisis bivariat bertujuan untuk mempelajari antara 2 variabel yaitu variabel independen dengan variabel dependen. Uji statistik yang digunakan yaitu chisquare, dengan menggunakan derajat kepercayaan $95 \%$. Bila $p$-value $<0,05$ berarti ada Hubungan Status ekonomi dan Pendidikan dengan kejadian Kekurangan Energi Kronis (KEK) pada Ibu Hamil di Puskesmas Talang Banjar Kota jambi, sedangkan pvalue >0,05 artinya tidak ada hubungan yang bermakna antara variabel independen dan variabel dependen ${ }^{8}$.

\section{HASIL}

Penelitian ini bersumber dari data yang diperoleh melalui pembagian lembar Kuesioner terhadap 60 responden di Puskesmas Talang Banjar Kota Jambi yang dilakukan oleh peneliti sendiri dengan cara Pembagian lembar Kuesioner terhadap responden yang datang ke Puskesmas Talang Banjar untuk melakukan pemeriksaan ANC sebagai alat ukur nya yaitu dengan 
mengukur Lingkar Lengan Atas (LILA) pada Ibu Hamil. Analisis penelitian ini dilakukan dengan menggunnakan Analisis Univariat dan Analisis Bivariat dimana hasil penelitian ini akan dilihat dalam bentuk distribusi frekuensi dan menghubungkan antara variabel bebas dan variabel terikat.

Analisa Univariat Status Ekonomi Tingkat Pendidikan Ibu Hamil dan Kejadian Kekurangan Energi Kronis (KEK) pada Ibu Hamil

Tabel 1

Distribusi frekuensi responden berdasarkan Ukuran LILA Ibu Hamil

\begin{tabular}{lccc}
\hline No & LILA Ibu Hamil & Jumlah & \% \\
\hline 1. & LILA $<23,5($ KEK) & 35 & 58,3 \\
\hline 2. & LILA $>23,5$ (Tidak & 25 & 41,7 \\
& KEK) & & \\
\hline & Total & 60 & 100 \\
\hline
\end{tabular}

Sumber : SPSS2016

Berdasarkan table 1 diatas dapat diketahui bahwa distribusi Responden yang memiliki ukuran LILA $<23,5 \mathrm{~cm}$ atau ibu hamil dengan KEK adalah 35 Responden $(58,3 \%)$, dan ibu hamil dengan ukuran LILA $>23,5 \mathrm{~cm}$ atau ibu hamil tidak KEK adalah 25 Responden $(41,7 \%)$.

Tabel 2

Distribusi frekuensi Gambaran Status Ekonomi Keluarga

\begin{tabular}{cccc}
\hline No & Status Ekonomi & F & \% \\
\hline 1 & Kurang & 29 & $48,3 \%$ \\
\hline 2 & Mampu & 31 & $51,7 \%$ \\
\hline & Total & 60 & $100 \%$ \\
\hline
\end{tabular}

Sumber : SPSS 2016

Berdasarkan table 2 dapat diketahui bahwa distribusi responden yang mempunyai Status Ekonomi kurang mampu yaitu sebanyak 29 responden $(48,3 \%)$, dan responden yang memiliki status Ekonomi Mampu yaitu sebanyak 31 responden $(51,7 \%)$.

Tabel 3

Distribusi frekuensi Gambaran Tingkat Pendidikan Ibu Hamil

\begin{tabular}{cccc}
\hline No & $\begin{array}{c}\text { Status } \\
\text { Pendidikan }\end{array}$ & F & \% \\
\hline 1 & Rendah & 35 & $58,3 \%$ \\
\hline 2 & Tinggi & 25 & $41,7 \%$ \\
\hline & Total & 152 & $100 \%$ \\
\hline
\end{tabular}

Sumber : SPSS 2016
Tabel 4

Distribusi frekuensi hubungan Status Ekonomi dengan Kejadian KEK pada Ibu Hamil di Puskesmas Talang Banjar Kota Jambi

\begin{tabular}{|c|c|c|c|c|c|c|c|c|}
\hline \multirow{4}{*}{$\begin{array}{l}\mathbf{N} \\
\mathbf{0}\end{array}$} & \multirow{4}{*}{$\begin{array}{c}\text { Status } \\
\text { Ekonomi }\end{array}$} & \multicolumn{4}{|c|}{ KEK } & \multirow{3}{*}{\multicolumn{2}{|c|}{ Total }} & \multirow{4}{*}{$\begin{array}{c}\text { OR } \\
95 \% \\
\text { C1 }\end{array}$} \\
\hline & & \multirow{2}{*}{\multicolumn{2}{|c|}{$\begin{array}{c}\text { LILA }< \\
23,5\end{array}$}} & \multirow{2}{*}{\multicolumn{2}{|c|}{$\begin{array}{c}\text { LILA > } \\
23,5\end{array}$}} & & & \\
\hline & & & & & & & & \\
\hline & & $\mathrm{F}$ & $\%$ & $\mathrm{~F}$ & $\%$ & $\mathrm{~F}$ & $\%$ & \\
\hline 1 & Kurang & 13 & 44,8 & 16 & 55,2 & 29 & 100 & 332 \\
\hline 2 & Mampu & 22 & 71 & 9 & 29 & 31 & 100 & \\
\hline & Total & 35 & 58,3 & 25 & 41,7 & 60 & 100 & (0) \\
\hline
\end{tabular}

Sumber : SPSS 2016

Berdasarkan Tabel 4 didapatkan hasil 60 responden tentang Status Ekonomi Ibu Hamil, didapat dari 31 responden dengan Status Ekonomi Mampu yang mengalami Kekurangan Energi Kronis (KEK) yaitu sebanyak 22 responden (71\%), dan dari 29 responden dengan Status Ekonomi Kurang Mampu yang mengalami Kekurangan Energi Kronis (KEK) yaitu sebanyak 13 responden (44.8\%).

Hasil uji statistic chi-square diperoleh nilai $p$ value $0.036(\mathrm{p}<0.05)$. maka dapat disimpulkan :

ada hubungan Status Ekonomi terhadap kejadian Kekurangan Energi Kronis (KEK) pada Ibu Hamil.

Nilai Odd Rasio/Faktor Resiko (OR) 0,332 (114 965) yang berarti ibu hamil dengan Status Ekonomi Kurang mampu memiliki peluang yang bermakna yaitu 332 kali ibu hamil dengan status ekonomi Kurang mengalami Kekurangan Energi Kronis (KEK) dibandingkan dengan ibu hamil yang memiliki status Ekonomi mampu.

Tabel 5

Distribusi frekuensi hubungan Tingkat Pendidikan dengan Kejadian KEK pada Ibu Hamil di Puskesmas Talang Banjar Kota Jambi

\begin{tabular}{|c|c|c|c|c|c|c|c|c|c|}
\hline \multirow{3}{*}{$\begin{array}{l}\mathbf{N} \\
\mathbf{0}\end{array}$} & \multirow{3}{*}{$\begin{array}{c}\text { Tingkat } \\
\text { Pendidik } \\
\text { an }\end{array}$} & \multicolumn{4}{|c|}{ KEK } & \multirow{2}{*}{\multicolumn{2}{|c|}{ Total }} & \multirow{3}{*}{$\begin{array}{c}\text { OR } \\
95 \% \\
\text { C1 }\end{array}$} & \multirow{3}{*}{$\begin{array}{l}\text { p- } \\
\text { val } \\
\text { ue }\end{array}$} \\
\hline & & \multicolumn{2}{|c|}{$\begin{array}{c}\text { LILA < } \\
23,5\end{array}$} & \multicolumn{2}{|c|}{$\begin{array}{c}\text { LILA > } \\
23,5\end{array}$} & & & & \\
\hline & & $\mathrm{F}$ & $\%$ & $\mathrm{~F}$ & $\%$ & $\bar{F}$ & $\%$ & & \\
\hline 1 & Rendah & 16 & 45,7 & 19 & 54,3 & 35 & 100 & 266 & 0.01 \\
\hline 2 & Tinggi & 19 & 76 & 6 & 24 & 25 & 100 & - & \\
\hline & Total & 35 & 58,3 & 25 & 41,7 & 60 & 100 & & \\
\hline
\end{tabular}

Sumber : SPSS 2016 
Berdasarkan table 5 didapatkan hasil 60 responden tentang Tingkat Pendidikan Ibu Hamil, didapat dari 25 responden dengan Tingkat Pendidikan Tinggi yang mengalami Kekurangan Energi Kronis (KEK) yaitu sebanyak 19 responden $(76 \%)$, dan 6 responden (24\%) yang tidak mengalami KEK, dari 35 responden dengan Tingkat Pendidikan Rendah yang mengalami Kekurangan Energi Kronis (KEK) yaitu sebanyak 16 responden $(45,7 \%)$.

Hasil uji statistic chi-square diperoleh nilai $p$ value $0.018 \quad(\mathrm{p}<0.05)$ disimpulkan ada hubungan Tingkat Pendidikan terhadap kejadian Kekurangan Energi Kronis (KEK) pada Ibu Hamil

Nilai Odd Rasio/Faktor Resiko (OR) 0,266 (086 826) yang berarti ibu hamil dengan Tingkat Pendidikan Rendah memiliki peluang yang bermakna yaitu 266 kali ibu hamil dengan Tingkat Pendidikan rendah mengalami Kekurangan Energi Kronis (KEK) dibandingkan dengan ibu hamil yang memiliki Tingkat Pendidikan tinggi dengan demikian dapat disimpulkan bahwa ada hubungan antara Tingkat Pendidikan dengan kejadian KEK pada Ibu Hamil di Puskesmas Talang Banjar KotaJambi.

\section{PEMBAHASAN}

Hubungan Status Ekonomi dengan kejadian Kekurangan Energi Kronis (KEK) di Puskesmas Talang Banjar Kota Jambi Tahun 2019.

Berdasarkan hasil penelitian, dari hasil 60 responden tentang Status Ekonomi Ibu Hamil, didapat dari 31 responden dengan Status Ekonomi Mampu yang mengalami Kekurangan Energi Kronis (KEK) yaitu sebanyak 22 responden (71\%), dan dari 29 responden dengan Status Ekonomi Kurang Mampu yang mengalami Kekurangan Energi Kronis (KEK) yaitu sebanyak 13 responden $(44.8 \%)$.

Dari hasil uji statistic chi-square diperoleh nilai $p$ value $0.036 \quad(\mathrm{p}<0.05)$ dan nilai Odd Rasio/Faktor Resiko (OR) 332 (114 - 965) ibu hamil yang mempunyai Status Ekonomi Kurang memiliki peluang yang bermakna yaitu 332 kali untuk mengalami Kekurangan Energi Kronis (KEK). dengan demikian dapat disimpulkan bahwa ada hubungan antara Status Ekonomi dengan kejadian KEK pada Ibu Hamil di Puskesmas Talang Banjar Kota Jambi.

Ibu hamil yang status ekonominya tinggi kemungkinan besar akan dapat mencukupi

kebutuhan gizi sehingga kebutuhan gizi ibu hamil akan tercukupi ${ }^{11}$. Ibu hamil yang status ekonomi tinggi juga akan melakukan pemeriksaan kehamilan sehingga membuat gizi ibu hamil semakin terpantau, sedangkan ibu hamil dengan status ekonomi yang rendah tidak memperhatikan kebutuhan gizi dan hygiene sanitasi makanan yang dikonsumsi sehingga ibu hamil sangat beresiko terkena penyakit infeksi ${ }^{11}$.
Berdasarkan hasil penelitian sebelumnya mengenai Faktor-faktor yang berhubungan dengan Kekurangan Energi Kronis (KEK) pada Ibu Hamil di wilayah kerja Puskesmas Rowosari Semarang menunjukkan bahwa Variabel status Ekonomi keluarga menunjukkan hasil bahwa terdapat hubungan antara status ekonomi dengan kejadian Kekurangan Energi Kronis (KEK) pada ibu hamil yaitu dengan nilai $\mathrm{p}=0,012(<0,05)^{5}$.

\section{Hubungan Tingkat Pendidikan dengan kejadian Kekurangan Energi Kronis (KEK) pada Ibu Hamil di Puskesmas Talang Banjar Kota Jambi tahun 2019.}

Berdasarkan hasil penelitian, dari 60 responden tentang Tingkat Pendidikan Ibu Hamil, didapat dari 25 responden dengan Tingkat Pendidikan Tinggi yang mengalami Kekurangan Energi Kronis (KEK) yaitu sebanyak 19 responden (76\%), dan dari 35 responden dengan Tingkat Pendidikan Rendah yang mengalami Kekurangan Energi Kronis (KEK) yaitu sebanyak 16 responden $(45,7 \%)$.

Dari hasil uji statistic chi-square diperoleh nilai $p$ value $0.018 \quad(\mathrm{p}<0.05)$ dan nilai Odd Rasio/Faktor Resiko (OR) 0,266 (086 - 826) ibu hamil yang mempunyai Tingkat Pendidikan Rendah memiliki peluang yang bermakna yaitu 266 kali untuk mengalami Kekurangan Energi Kronis (KEK). dengan demikian dapat disimpulkan bahwa ada hubungan antara Tingkat Pendidikan dengan kejadian KEK pada Ibu Hamil di Puskesmas Talang Banjar Kota Jambi.

Pendidikan merupakan proses belajar yang mengarahkan seseorang kearah yang lebih dewasa, lebih baik dan lebih matang dari individu ${ }^{11}$. Tingkat Pendidikan mempengaruhi perilaku seseorang dalam memilih makanan. Makanan yang seimbang dan beragam akan membantu mencegah terjadinya Kekurangan Energi Kronis (KEK) ${ }^{11}$.

Tingkat pendidikan seseorang dapat mendukung atau mempengaruhi tingkat pengetahuan yaitu semakin tinggi pendidikan maka semakin tinggi pengetahuan seseorang karena pendidikan yang tinggi mempermudah ibu menerima informasi baru sehingga tidak akan acuh terhadap informasi kesehatan ${ }^{12}$.

Berdasarkan hasil penelitian sebelumnya mengenai Faktor-faktor yang berhubungan dengan kejadian Kekurangan Energi Kronis (KEK) pada Ibu hamil di Wilayah Kerja Puskesmas Krueng Barona Jaya Kabupaten Aceh Besar menunjukkan bahwa kejadian Kekurangan Energi Kronis (KEK) pada ibu hamil yang berpendidikan rendah lebih banyak terjadi pada kelompok status yaitu $85 \%$, sementara pada kelompok control hanya $30 \%{ }^{3}$. Hasil uji statistic diperoleh nilai $\mathrm{OR}=13,2$ yang berarti bahwa ibu hamil yang berpendidikan rendah mempunyai peluang 13,2 kali lebih besar mengalami KEK dibandingkan yang berpendidikan tinggi ${ }^{3}$. 


\section{KESIMPULAN}

Berdasarkan hasil penelitian serta pembahasan tentang hubungan Status Ekonomi dan Tingkat Pendidikan dengan kejadian Kekurangan Energi Kronis (KEK) pada Ibu Hamil di Puskesmas Talang Banjar Kota Jambi, maka diperoleh kesimpulan bahwa sebanyak 35 responden $(58,3 \%)$ mengalami Kekurangan Energi Kronis (KEK) dengan LILA $<23,5 \mathrm{~cm}$ dan 25 responden $(41,7 \%)$ tidak mengalami Kekurangan Energi Kronis (KEK) dengan LILA $>23,5$ cm., sebanyak 29 responden (48,3\%) mempunyai Status Ekonomi Kurang dan 31 responden $(51,7 \%)$ mempunyai Status Ekonomi mampu, sebanyak 35 responden $(58,3 \%)$ memiliki Tingkat Pendidikan rendah dan 25 responden $(41,7 \%)$ memiliki Tingkat pendidikan tinggi, adanya hubungan antara Status Ekonomi dengan kejadian Kekurangan Energi Kronis (KEK) pada Ibu Hamil di Puskesmas Talang Banjar Kota Jambi nilai p-value 0,036 dan nilai $\mathrm{OR}=332(114-965)$, adanya hubungan antara Tingkat Pendidikan dengan kejadian Kekurangan Energi Kronis (KEK) pada Ibu Hamil di Puskesmas Talang Banjar Kota Jambi.

\section{DAFTAR PUSTAKA}

1. Kementrian Kesehatan RI. 2016. Infodatin Situasi Gizi diindonesia. Jakarta: Kementrian Kesehatan RI

2. Kemenetrian Kesehatan RI. 2018. Profil Kesehatan Indonesia 2017. Jakarta: Kementrian Kesehatan RI.

3. RS Renjani, dkk - JOURNAL OF HEALTHCARE TECHNOLOGY AND MEDICINE 3 (2), 254-270, 2017 jurnal.uui.ac.id

4. Winarsih. 2018. Pengantar Ilmu Gizi dalam Kebidanan. Yogyakarta: Pustaka Baru

5. YD Novitasari, dkk - JURNAL KEDOKTERAN DIPONEGORO 8 (1), 562-571,2019 ejournal3.undip.ac.id

6. Dinas Kesehatan Kota Jambi. 2018. Data Bulanan Puskesmas Talang Banjar Kota Jambi 2018

7. Sulistyoningsih. 2011. Gizi Untuk Kesehatan Ibu dan Anak. Yogyakarta: Graha Ilmu.

8. Notoatmodjo, S. 2010. Metodologi penelitian kesehatan. Jakarta : Rineka Cipta

9. Kristianasari W, 2010. Gizi Ibu Hamil. Yogyakarta: Nuha Medika

10. Notoatmodjo, S. 2012. Promosi Kesehatan dan Perilaku kesehatan. Jakarta : Rineka Cipta

11. Irianti, 2014.Asuhan Kebidanan Kegawatdaruratan Kehamilan.jakarta
12. Notoatmodjo. 2011. Kesehatan Masyarakat : Ilmu dan Seni, Jakarta : Rineka Cipta 